Jurnal Sistem Informasi (Journal of Information Systems). 1/12 (2016), 15-29

DOI: http://dx.doi.org/10.21609/jsi.v12i1.457

\title{
ANALISA DAN PERENCANAAN STRATEGIS SISTEM DAN TEKNOLOGI INFORMASI MENGGUNAKAN BALANCE SCORECARD PADA INSTITUT BISNIS DAN INFORMATIKA KWIK KIAN GIE
}

\author{
Yunus Fadhillah dan Jesaja Waterkamp \\ Fakultas Teknik Informatika, Institut Bisnis dan Informatika Kwik Kian Gie \\ Jl. Laksamana Yos Sudarso Kav. 8, Jakarta, 14230, Indonesia \\ E-mail: yunus.fadhillah@kwikkiangie.ac.id
}

\begin{abstract}
The advancement of an institution is determined by vision, mission and goals of the institution which is essentially supported by all components of the institution, controlled by strong leadership using the implementation of the balanced scorecard approach. Alignment and management of information technology in providing facilities and infrastructure to support the objectives of the institution in achieving world class university level, which refers to several criteria such as Higher Education, ARWU and Webometric do using COBIT Framework. An investigation of the need and development of qualified human resources in supporting these activities are done using the Zachman Framework. Using the above approach, an Information Technology roadmap is designed to be constructed within a period of 15 years, divided into three categories, namely network and infrastructure, Information Systems and Organizations Systems which each of the categories is divided again into 3 stages of 5year development.
\end{abstract}

Keywords: IT Governance, IT Strategic Planning, SWOT Analysis

\begin{abstract}
Abstrak
Kemajuan suatu institusi sangat ditentukan oleh visi, misi dan tujuan institusi tersebut yang didukung secara sungguh-sungguh oleh semua komponen institusi serta dikendalikan dengan kepemimpinan yang kuat dan diimplementasikan dengan pendekatan balanced scorecard. Penyelarasan dan pengelolaan teknologi informasi dalam menyediakan sarana dan prasarana untuk mendukung tujuan institusi dalam mencapai tingkatan world class university yang mengacu kepada beberapa kriteria seperti DIKTI, ARWU dan Webometric dilakukan dengan COBIT Framework. Investigasi akan kebutuhan dan pengembangan sumber daya manusia yang berkualitas dalam mendukung kegiatan tersebut dilakukan dengan menggunakan Zachman Framework. Dengan menggunakan pendekatan di atas maka didapat roadmap Teknologi Informasi yang akan dibangun dalam jangka waktu 15 tahun yang dibagi ke dalam 3 kategori, yaitu jaringan \& infrastruktur, Sistem Informasi, dan Sistem Organisasi yang masing-masing kategori dibagi ke dalam 3 tahapan 5 tahunan.
\end{abstract}

Kata Kunci: tata kelola teknologi informasi, perencanaan strategis teknologi informasi, analisa SWOT

\section{Pendahuluan}

Institut Bisnis dan Informatika Kwik Kian Gie (IBI KKG) merupakan salah satu institusi pendidikan tinggi yang turut bertanggung jawab dalam pengembangan sumber daya manusia Indonesia senantiasa berusaha menyumbangkan yang terbaik untuk Indonesia. Semua kalangan Institut Bisnis dan Informatika Kwik Kian Gie menyadari bahwa visi, misi, dan kepemimpinan mempunyai daya dorong kemajuan yang sangat menentukan. Perubahan dunia teknologi sangat berkembang dengan pesat serta dinamika perubahan yang terus menerus terjadi, menyebabkan Departemen Teknologi Informasi dan Komputer (ICT) di dalam organisasi IBI KKG harus dapat mendukung dan meningkatkan ambisi, visi, misi dan tujuan organisasi yang dianut oleh Institut ini.

Excellence, Distinctiveness, Growth and Engagement (EDGE) telah di diidentifikasikan sebagai pilar perencanaan IBI KKG serta akan dikembangkan dan dikelola secara terus menerus. Oleh karena itu, Rencana Strategis harus dapat menjadi garis besar aspirasi masa depan terhadap penggunaan Teknologi Informasi dan Komunikasi dalam lingkungan IBI KKG serta dapat memberikan penyebaran pelayanan teknologi informasi, proses pengambilan keputusan yang tepat maupun perencanaan pengembangan sistem perangkat keras dan lunak bagi seluruh komunitas dalam kampus IBI KKG. 
TABEL 1

Tahapan Program Pengembangan Perguruan TINGGI DITJEN DIKTI

\begin{tabular}{ll}
\hline Periode & Tema Pengembangan \\
\hline $2005-2010$ & Peningkatan Kapasitas \& Modernisasi \\
$2010-2015$ & Penguatan Pelayanan \\
$2015-2020$ & Daya Saing Regional \\
$2020-2025$ & Daya Saing Internasional \\
\hline
\end{tabular}

Adapun visi yang dimiliki organisasi ini adalah menjadi salah satu school of business terkemuka di Indonesia yang berwawasan regional dan internasional, dengan kualitas unggul berdasarkan standard World Class University, dikenal oleh masyarakat luas, serta diakui oleh dunia usaha. Organisasi ini juga memiliki misi untuk membentuk insan profesional, pengusaha, dan pimpinan masa depan yang kompeten dalam bidang bisnis yang berwawasan regional dan internasional, melalui proses pembelajaran, penelitian, dan pengabdian kepada masyarakat yang berkualitas.

Tujuan jangka panjang yang ingin dicapai adalah menjadi Universitas Kelas Dunia atau saat ini dikenal dengan World Class University (WCU). Maka dari itu, sebagai tahapan pertama dalam mendukung tujuan jangka panjang harus dibentuk lingkungan kampus berbasis digital atau digital campus. Terdapat beberapa pandangan dasar mengenai pemahaman WCU ini.

\section{Berdasarkan Direktorat Jendral Pendidikan Tinggi (DIKTI)}

Direktorat Jendral Pendidikan Tinggi Departemen Pendidikan telah mencanangkan program pengembangan pendidikan tinggi dalam tahapan 5 tahunan yang dapat dijelaskan dalam bentuk Tabel 1 . DIKTI memiliki versi tersendiri mengenai acuan universitas kelas dunia. Hal ini dijadikan sebagai acuan juga oleh universitas atau institusi pendidikan di Indonesia, yaitu sesuai dengan surat Ditjen Dikti No.2045/D/T/2007 tanggal 25 Juli 2007 [1], dijelaskan mengenai WCU pada Lampiran Tabel I. Dari 34 kriteria pada Lampiran Tabel I, maka oleh Ditjen DIKTI terbagi menjadi menjadi 5 subkriteria yang masing-masing mempunyai bobot tersendiri. Adapun pembagian sub-kriteria dari Ditjen DIKTI terbagi menjadi: Awards (30\%), Student Life (20\%), Facilities (10\%), Research \& Communities Services (25\%), International Collaboration $(15 \%)$. Sedangkan kriteria dari beberapa lembaga pemberi akreditasi WCU sangat berbeda dengan kriteria yang dicanangkan oleh DIKTI.

\section{Berdasarkan Times Higher Education Supple- ment (THES)}

Times Higher Education (THE) atau lebih dikenal dengan Times Higher Education Supplement (TH-
TABEL 2

KRITERIA DAN INDIKATORS THES

\begin{tabular}{lll}
\hline Kriteria & Indikator & $\begin{array}{l}\text { Bobot } \\
\text { Penilaian }\end{array}$ \\
\hline Kualitas riset & Peer review & $40 \%$ \\
& Sitasi per dosen & $20 \%$ \\
Keterserapan lulusan & Review perekrut & $10 \%$ \\
Citra internasional & Dosen internasional & $5 \%$ \\
& Mahasiswa & $5 \%$ \\
Kualitas Pengajaran & internasional & \\
Total & Dosen & $20 \%$ \\
\hline
\end{tabular}

ES) merupakan majalah mingguan yang berbasis di London, secara khusus melaporkan berita dan masalah terkait pendidikan tinggi. Kriteria berdasarkan THES dalam menilai dan memberikan rangking untuk World Class University dapat dilihat pada Tabel 2 [2].

Secara detail komposisi skema penilaian World Class University dalam penilaian THES dapat dilihat pada Lampiran Gambar I.

\section{Berdasarkan Shanghai Jiao Tong University (ARWU)}

Shanghai Jiao Tong University merupakan universitas riset publik yang berada di Shanghai, China. Academic Rangking of World University (ARWU) diterbitkan pertama kali pada Juni 2003 oleh Center for World Class University (CWCU) Shanghai Jiao Tong University dan diperbaharui setiap tahun. ARWU menggunakan 6 indikator objektif yang dapat dilihat pada Tabel 3 untuk menentukan peringkat universitas kelas dunia [3].

Tujuan ARWU di awal untuk mendirikan universitas global Cina. Akan tetapi banyak dikutip hasil laporannya oleh berbagai universitas di dunia dikarenakan menggunakan metodologi secara ilmiah, stabil dan transparan.

\section{Berdasarkan WEBOMETRIC}

Webometrics adalah salah satu perangkat atau sistem untuk mengukur dan memberikan penilaian terhadap kemajuan seluruh universitas atau perguruan tinggi terbaik di dunia (World Class University) melalui website universitas tersebut.

Kriteria World Class University menurut Webometrics [4], lebih banyak ditekankan kepada penyajian data-data capaian kinerja perguruan tinggi yang dapat diakses melalui website. Dengan demikian, jika versi ini yang ingin dicapai, maka pemutakhiran data-data di website IBI KKG harus menjadi prioritas utama kita semua. Adapun kriteria penilaian World Class University berdasarkan webometric pada Tabel 4.

Data peringkat perguruan tinggi berdasarkan penilaian web universitas ini diperbaharui setiap 6 bulan secara independen, bebas, terbuka secara ilmiah. 
TABEL 3

\begin{tabular}{|c|c|c|}
\hline Kriteria & Indikator & Bobot \\
\hline $\begin{array}{l}\text { Kualitas } \\
\text { pendidikan }\end{array}$ & $\begin{array}{l}\text { Alumni yang memenangi Hadiah } \\
\text { Nobble dan Field Medals. }\end{array}$ & $10 \%$ \\
\hline Kualitas & Pengajar yang memenangi & $20 \%$ \\
\hline pengajar & $\begin{array}{l}\text { Hadiah Nobble dan Field Medals. } \\
\text { Riset yang paling disitir dalam } 21 \\
\text { kategori. }\end{array}$ & $20 \%$ \\
\hline Luaran riset & $\begin{array}{l}\text { Artikel ilmiah yang dipublikasi di } \\
\text { Majalah } \\
\text { Nature dan Majalah Science. } \\
\text { Artikel yang disitir oleh Science } \\
\text { Citation } \\
\text { Index. }\end{array}$ & $20 \%$ \\
\hline $\begin{array}{l}\text { Ukuran } \\
\text { institusi }\end{array}$ & $\begin{array}{l}\text { Performa akademik dalam } \\
\text { kaitannya dengan } \\
\text { ukuran institusi. }\end{array}$ & $10 \%$ \\
\hline Total & & $100 \%$ \\
\hline
\end{tabular}

\section{Metode}

Metodologi yang dilakukan penulis dengan menggunakan beberapa kerangka metodelogi dan pendekatan.

\section{Balanced Scorecard}

Balanced scorecard merupakan pendekatan untuk mengukur kinerja suatu organisasi atau departemen yang cukup komprehensif dan mampu melipat gandakan kinerja di masa yang akan datang [5].

Penurunan balanced scorecard [6] di dalam organisasi ini diturunkan dari visi dan misi organisasi ke dalam 4 perspektif, yaitu: keuangan, bisnis proses organisasi, mahasiswa \& pihak yang berkepentingan, serta pembelajaran dan inovasi. Setiap perfektif mempunyai tujuan, indikator penilaian, pengukuran, target yang dicapai dan tindakan yang dilakukan untuk mencapai target tersebut yang saling berkaitan erat.

\section{Zachman Framework}

Pengembangan sumber daya manusia pada pada setiap departemen terutama pada Information Communication Technology (ICT) menggunakan konsep berpikir dengan menerapkan dan melaksanakan kegiatan kerja setiap individu berbasis What, How, Where, Who, When dan Why dalam setiap pengembangannya [7][8].

Zachman Framework (Lampiran Gambar II), merupakan pembentukan sumber daya manusia pada organisasi mengikuti pola kerangka pemikiran di atas, disadari bukanlah merupakan hal yang mudah. Beberapa pendekatan akan dilakukan dalam membentuk pribadi setiap individu dalam organisasi yang antara lain, melakukan pembelajaran secara internal dalam lingkungan organisasi dan departemen atau bagian, melakukan pelatihan berkelompok yang dilakukan internal dan ekster-
TABEL 4

\begin{tabular}{l} 
KRITERIA PENILAIAN WEBOMETRIC \\
\hline \multicolumn{3}{c}{ Kriteria Ukuran Bobot } \\
\hline Jumlah halaman referensi tentang IBIKKG dan si- \\
vitas akademikanya, yang dapat didapatkan mela- \\
lui mesin pencari Google, Yahoo, Live Search, \\
dan Exalead. \\
Jumlah link eksternal yang berkaitan dengan IBI \\
KKG dan sivitas akademikanya, yang dapat \\
diakses melalui mesin pencari (Yahoo dan MSN). \\
Adanya dokumen-dokumen dalam format Adobe \\
Acrobat PDF, Adobe Postcript, Micro-soft Word, \\
dan Microsoft Powerpoint dari artikel-artikel \\
akademik sivitas akademika IBIKKG yang dapat \\
diekstrak dari internet. \\
Melalui mesin pencari Google terdeteksi sejumlah \\
artikel dan sitasi dari setiap akademisi. Kepakaran \\
akademisi IBI KKG harus dapat terdeteksi oleh \\
mesin pencari Google di internet.
\end{tabular}

nal maupun pendekatan lainnya baik secara aturan, kebijakan dalam organisasi IBI KKG maupun petunjuk serta pengarahan langsung dari atasannya.

\section{Control Objective for Information and related Technology (COBIT) Framework}

Tata kelola teknologi informasi mempunyai banyak sekali tools, salah satunya adalah COBIT (Control OBjective for Information and related Technology) Framework yang ditampilkan pada Lampiran Gambar III [9]. COBIT Framework menyediakan ukuran, indikator, proses dan kumpulan praktisi terbaik dalam membantu organisasi mencapai optimalisasi dari pengelolaan teknologi informasi dan pengendalian terhadap manajemen teknologi informasi yang cocok untuk suatu organisasi.

Secara umum, COBIT terbagi menjadi empat domain besar, yaitu Planning and Organisation (PO), Acquisition and Implementation (AI), Delivery and Support (DS), Monitoring and Evaluate (ME). Selanjutnya, untuk memenuhi tujuan bisnis, informasi memerlukan kriteria pengendalian tertentu, yang dalam hal ini didefinisikan oleh COBIT sebagai efektivitas, efisiensi, kerahasiaan, integritas, ketersediaan, kepatuhan, dan keandalan.

Efektivitas (effectiveness), terkait dengan informasi relevan dan berhubungan pada proses bisnis dalam penyampain secara tepat waktu, benar, dan konsisten. Efisiensi (efficiency), terkait dengan ketentuan informasi melalui penggunaan sumber daya yang optimal. Kerahasiaan (confidentiality), terkait dengan pengamanan informasi yang sensitif dari pihak yang tidak berhak. Integritas (integrity), terkait dengan akurat dan kelengkapan informasi serta validitasnya sesuai dengan harapan bisnis. Ketersediaan (availability), terkait dengan informasi yang tersedia dan dapat diakses kapanpun oleh pengguna bisnis. Kepatuhan (com- 


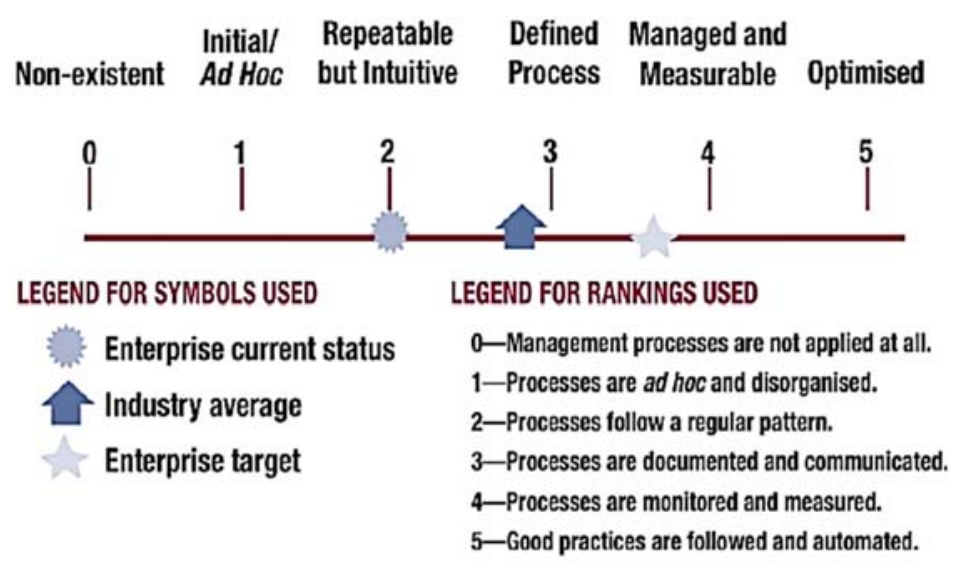

Gambar 1. Maturity Model

pliance), terkait dengan aturan, kebijakan maupun regulasi. Keandalan (reliability) terkait dengan penyediaan informasi yang tepat bagi manajemen dalam mendukung operasional maupun tanggung jawab tata kelolanya.

Adapun pembagian IT resources menurut COBIT Framework terbagi menjadi 5 bagian yaitu data, application systems, technology, facilities, dan people. Data, sebagai obyek dalam pengertian yang luas, baik terstruktur maupun tidak, bentuk grafis, suara dan lainnya. Application systems, merupakan kumpulan prosedur manual maupun coding untuk aplikasi. Technology, meliputi perangkat keras, sistem operasi komputer, Manajemen database, jaringan, multimedia dan hal lainnya yang digunakan dalam Institusi. Facilities, merupakan semua kumpulan sumber daya dalam mendukung sistem informasi dalam suatu organisasi/institusi. People, termasuk di dalamnya staff skills, kepedulian, produktivitas, hingga pengawasan sistem informasi maupun pelayanannya. Bentuk COBIT secara utuh dapat digambarkan seperti pada Lampiran Gambar III.

\section{COBIT Maturity Level Sebagai Alat Benchmark Kematangan Teknologi Informasi.}

Maturity Model [10] menggunakan pendekatan evaluasi organisasi, sehingga setiap organisasi dapat melakukan evaluasi tata kelola IT berdasarkan tingkat kematangan dari non-existent hingga optimized yang ditunjukan pada Gambar 1 .

0-Non-existent adalah kondisi dimana organisasi sama sekali tidak peduli terhadap pentingnya IT untuk dikelola dengan baik.

Ad-hoc adalah kondisi di mana organisasi secara reaktif melakukan penerapan dan implementtasi ICT sesuai dengan kebutuhan-kebutuhan mendadak yang ada tanpa melalui perencanaan sebe- lumnya; Repeatable adalah kondisi dimana organisasi telah memiliki pola yang berulang da-lam melakukan tata kelola ICT, namun aktivitas-nya belum terdefinisi dan terdokumentasi dengan baik secara formal sehingga belum konsisten dilakukan; Defined adalah kondisi dimana organisasi telah memiliki prosedur baku formal dan tertulis yang telah disosialisasikan ke segenap jajaran manajemen dan karyawan untuk dipatuhi dan dijalankan dalam aktivitas sehari-hari; Managed adalah kondisi dimana organisasi telah memiliki sejumlah indikator dan ukuran kuantitatif yang menjadi sasaran obyektif kinerja dari setiap implementasi sistem Teknologi Infor-masi; Optimized adalah kondisi dimana organisasi dianggap telah mengimplementasikan tata kelola Teknologi Informasi sesuai dengan best practice.

\section{Goal \& Metrics Sebagai Alat Ukur Keluaran dan Kinerja Teknologi Informasi.}

Saat ini sedang dilakukan penyusunan alat ukur tata kelola IT (Information Technology) sesuai dengan 4 domain yang terdapat dalam COBIT. Penyu-sunan tujuan dan ukuran tersebut mengikuti panduan pada Gambar 2.

\section{Activity Goal Sebagai Pengendalian Proses Te- knologi Informasi.}

Activity goal (tujuan kegiatan) merupakan target dari suatu kegiatan yang harus dicapai dan merupakan pengendalian dari suatu proses kegiatan teknologi informasi dalam 4 domain besar tadi. Karena berukuran besar, bagan yang menunjukkan tujuan kegiatan ini terdapat pada Lampiran Gambar IV.

Penggunaan kombinasi beberapa metode di atas meskipun secara keseluruhan pada kerangka 


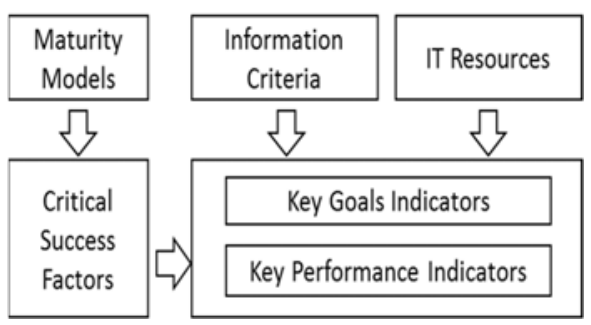

Gambar 2. Panduan tata kelola IT dan penyusunan alat ukur keluaran dan kinerja teknologi informasi

COBIT sudah termasuk metode balanced scorecard [11] maka secara gambaran besarnya terdapat pada Gambar 3.

Mulai dari visi \& misi, tujuan, indikator penilaian, pengukuran, target yang dicapai dan tindakan yang dilakukan untuk mencapai target tersebut dari masing masing domain model yang dikategorikan dengan pembagian dalam konteks teknologi informasi agar mempermudah pemahaman dan hasil penelitian digambarkan secara rinci pada Gambar 4.

\section{Hasil dan Analisis}

Hasil dan analisa penelitian dari metode-metode di atas terhadap organisasi IBI KKG dari sudut pandang Teknologi Informasi terhadap institusi ini dan dibagi ke dalam 3 kategori, yaitu perangkat lunak (Software), perangkat keras (Hardware) dan sumber daya manusia. Analisa terhadap Critical Success Factors (CSF), Key Goal Indicators dan Key Performance Indicator (KPI) institusi IBI KKG secara garis besar telah dituangkan pada standar penjaminan mutu internal pendidikan tinggi (SPMI-DIKTI).

Tingkat kematangan teknologi informasi pada IBI KKG dapat digambarkan pada Gambar 5. Kondisi saat ini pada level 1 dimana terjadi kekacauan pada pengembangan sistem informasi dengan para developer menggunakan metode masing-masing, infrastruktur jaringan tumpang tindih serta tidak terdokumentasi.

Kebutuhan dan kondisi perangkat lunak maupun sistem informasi yang dibutuhkan oleh organisasi ini dapat dilihat pada bagian Lampiran Tabel II. Sementara kebutuhan akan perangkat keras, kondisi infrastruktur dan topologi jaringan saat ini digambarkan pada Lampiran Gambar V.

Organisasi secara keseluruhan dan pada umumnya adalah sudah sesuai dengan institusi lainnya, penulis hanya fokus ke departemen IT yang sangat berpengaruh dalam mewujudkan Kampus Digital sehingga mampu menyelaraskan dengan kebutuhan organisasi. Susunan hierarki saat ini tergambar pada Gambar 6 .

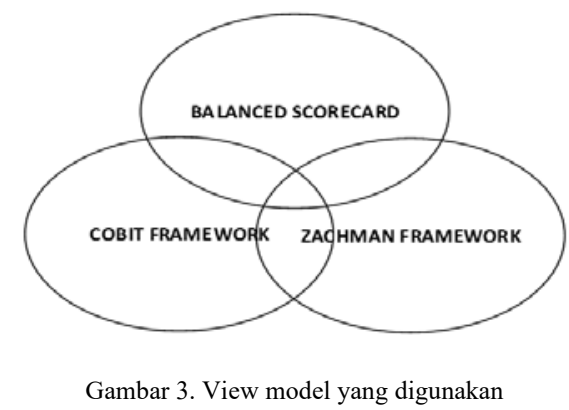

Secara umum, pekerjaan pada bagian workshop adalah melakukan pemantauan terhadap seluruh peralatan elektronik yang ada di kelas maupun yang digunakan oleh seluruh karyawan IBI KKG. Adapun pekerjaan dari WEB Developer secara umum terbagi menjadi dua bagian besar yaitu, pengembangan sistem informasi berbasis web dan pengembangan terhadap web desain dalam memberikan informasi profil institusi pada dunia luar.

EDP berfungsi dalam melalukan pemeliharaan dan pengembangan aplikasi untuk kebutuhan internal, seperti sistem informasi akademik atau yang dikenal dengan SIASI serta integrasi yang terkait dengan bagian lainnya seperti keuangan maupun personalia.

Fungsi utama dari administrasi network adalah mengatur dan memelihara data yang ada dalam database serta pengaturan terhadap koneksi jaringan Internet maupun jaringan lokal dalam kampus IBI KKG. Di antara hasil-hasil yang dicapai adalah sebagai berikut:

\section{Perangkat Lunak}

Pengembangan sistem informasi dapat dipilah menjadi dua bagian besar dimana keduanya saling terintegrasi, yaitu sistem informasi terkait dengan kegiatan akademik maupun kegiatan institusi. Sistem informasi yang terkait dengan kegiatan akademik yaitu merupakan sistem informasi yang mencatat data calon mahasiswa, kegiatan selama menjadi mahasiswa hingga kelulusannya. Sistem informasi yang terkait dengan kegiatan institusi yaitu, proses pembelian hingga persediaan barang, asset maupun kegiatan dalam proses keuangan. Pelaporan merupakan informasi yang dibutuhkan oleh manajemen institusi dalam mengawasi maupun memahami mengenai kegiatan operasional dan tertuang dalam sistem informasi eksekutif.

\section{Sistem Informasi Akademik}

Fokus dalam pengembangan Sistem Informasi Akademik difokuskan mulai dari proses penerima- 


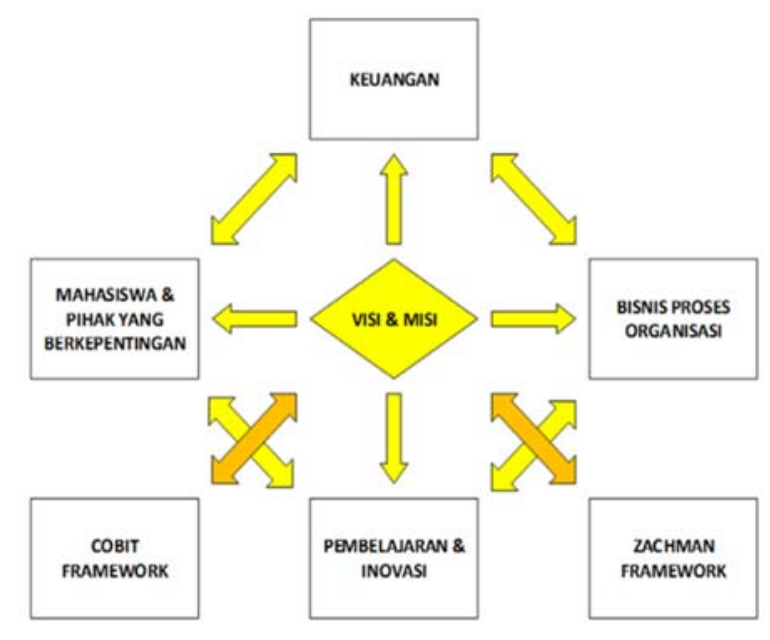

Gambar 4. Detail model yang digunakan.

an mahasiswa baru, proses kegiatan akademik selama menjadi mahasiswa hingga proses pencatatan data alumni IBII. Proses utama terbagi menjadi empat mega proses yaitu sebagai berikut:

\section{Student Administration}

Kegiatan dalam beberapa proses besar terbagi menjadi: 1) Skenario pencatatan mahasiswa baru hingga menjadi mahasiswa; 2) Skenario pencatatan administrasi kegiatan mahasiswa selama kuliah di IBII; 3) Skenario pencatatan wisuda dan alumni; 4) Skenario pelayanan mandiri untuk mahasiswa (student self service) dan orang tua (parent self service); 5) Skenario pelayanan mandiri untuk pengajar (lecturer self service).

\section{Student Accounting}

Kegiatan utama dalam proses Student Accounting adalah proses pembayaran perkuliahan, dimulai dari pendaftaran mahasiswa baru hingga wisuda mahasiswa, yaitu: 1) Skenario pembayaran calon mahasiswa; 2) Skenario pembayaran perkuliahan dalam kegiatan akademik; 3) Skenario pembayaran lain lain hingga pencatatan pembayaran di bagian keuangan; 4) Skenario informasi pembayaran melalui pelayanan mandiri untuk mahasiswa dan orang tua;

\section{Teaching and Study}

Kegiatan dalam proses Teaching and study adalah mekanisme pengambilan rencana kuliah, proses perubahan pengambilan kuliah hingga persetujuan dan pembayaran perkuliahan. Skenario kegiatan yang termasuk dalam mega proses ini adalah: 1) Sub-skenario pengisian nilai rencana belajar dan merupakan bagian dari skenario pencatatan administrasi kegiatan mahasiswa; 2) Sub-skenario pencatatan laporan hasil belajar dan nilai akademik dan merupakan bagian dari skenario pencatatan administrasi kegiatan mahasiswa dan skenario pembayaran perkuliahan dalam kegiatan akademik.

Event Planning.

Event Planning, intinya adalah termasuk dalam skenario pencatatan administrasi kegiatan mahasiswa yang secara khusus menangani mengenai penjadwalan kegiatan perkuliahan, baik itu merupakan jadwal kuliah secara regular per setiap semester ataupun proses penjadwalan mengenai ujian per matakuliah maupun untuk kegiatan rencana penjadwalan lainnya, seperti proses ujian saringan masuk, proses jadwal matrikulasi dan lainnya.

\section{Sistem Informasi Institusi}

Sistem informasi Institusi merupakan sebuah sub sistem pendukung secara tidak langsung dengan sistem informasi akademik dan merupakan kegiatan dari institusi itu sendiri dalam beberapa skenario lainnya untuk kepentingan institusi itu sendiri. Adapun mega proses yang ada dalam sistem informasi institusi adalah:

\section{E-Procurement.}

Merupakan sistem informasi yang akan mencatat mengenai permintaan barang dari setiap bagian, selanjutnya akan dilakukan proses pembelian secara terpusat. Skenario utama adalah pembelian barang dan jasa serta distribusi permintaan tersebut kepada unit yang meminta, merupakan kegiatan utama dari proses e-procurement ini. Permintaan barang melalui setiap unit dalam organi-sasi IBI KKG, pengumpulan permintaan barang dan dilakukan pengadaan serta distribusi kepada unit yang membutuhkan. 


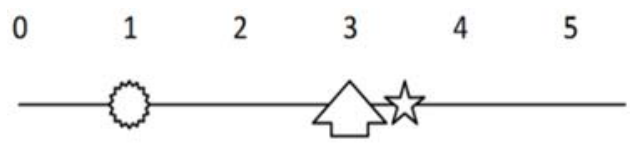

Gambar 5. IBI KKG IT maturity level

\section{E-Inventory}

Sistem informasi yang mencatat mengenai barang masuk dan keluar. Proses ini terkait dengan Sistem informasi e-procurement, dimana pengadaan barang akan terlebih dahulu dilakukan pengecekan dengan bagian Inventory, bila barang tersebut telah tersedia, maka proses akan mendistribusikan barang yang dimaksud.

\section{E-Asset}

Sistem informasi ini akan melakukan pencatatan terhadap semua barang yang merupakan asset dari IBII. Proses permintaan barang yang bersifat menjadi asset, seperti laptop, switch komputer, meja dan lainnya, akan dilakukan pencatatan termasuk di dalamnya yaitu pemakai dari aset tersebut. Skenario utama adalah pencatatan aset hingga distribusi aset kepada pemakai maupun perpindahan aset merupakan informasi yang akan tersimpan dalam sistem.

\section{Finance \& Accounting}

Sebagai pusat dari semua kegiatan proses yang pada akhirnya akan bermuara pada kegiatan keuangan. Secara umum, skenario dari sistem keuangan ini akan terdiri dari General Ledger (GL), Account Receiveable (AR), Account Payable (AP), Bank, asset serta keterkaitannya dengan pelaporan maupun informasi mengenai biaya-biaya yang terkait. Terdapat dua pendekatan yaitu menggunakan sistem informasi keuangan yang sudah ada dan dilakukan beberapa pengembangan terkait atau dilakukan pengembangan sistem keuangan yang spesifik untuk kebutuhan IBI KKG.

\section{Human Capital Management}

Sistem informasi Human Capital Management (HCM) adalah sistem informasi yang mencatat dan mengolah data karyawan untuk kebutuhan administrasi, proses pengolahan manajemen waktu, proses penyusunan jadwal pelatihan, proses penerimaan karyawan baru, hingga pengembangan sistem informasi untuk kebutuhan terhadap career plan ataupun succession plan. Pengembangan sistem informasi HCM akan dilakukan secara bertahap. Target tahap pertama akan difokuskan pada skenario administratif pendataan karyawan dan pengolahan manajemen waktu termasuk di dalamnya adalah presensi data per karyawan.

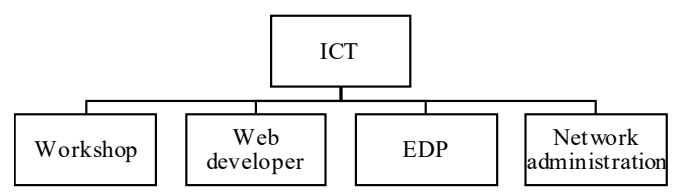

Gambar 6. Struktur organisasi IT saat ini

\section{Sistem Informasi Ekesekutif}

Sistem informasi Eksekutif adalah merupakan penyajian analisa laporan kepada manajemen IBI KKG maupun kepada stakeholder. Informasi ini tentunya berdasarkan data transaksi yang terjadi baik dari sistem informasi akademik maupun dari sistem informasi institusi. Oleh karena itu, secara bertahap akan disusun mengenai kebutuhan laporan analisa secara bertahap dan dapat digunakan sebagai informasi yang membantu dalam melakukan keputusan yang tepat untuk kegiatan organisasi IBI KKG.

Pengembangan Sistem Informasi Eksekutif akan dilakukan dengan menyusun data warehouse sebagai pusat data dari semua sistem informasi yang ada maupun yang akan dicanangkan, selanjutnya penyajian dashboards dan scorecards menjadi tujuan utama dalam memberikan knowledge kepada manajemen IBII terhadap kumpulan informasi dalam institusi KKG.

\section{Sistem Informasi Pendukung}

Sistem informasi pendukung terdiri dari beberapa informasi yang terpisah satu sama lainnya, mempunyai keterkaitan tidak secara langsung. Akan tetapi, membutuhkan informasi baik dari Sistem Informasi Akademik, Institusi maupun Eksekutif. Beberapa sistem informasi pendukung yang telah tercatat sebagai kebutuhan institusi IBI KKG adalah sebagai berikut: Sistem Informasi Perpustakaan, Sistem Informasi Jurnal Ilmiah dan Riset, Sistem informasi E-Learning, Sistem Informasi Data Management, Portal Web IBI KKG.

Secara umum, seluruh skenario kegiatan akademik yang telah dijelaskan sebelumnya, dapat digambarkan seperti dalam Lampiran Gambar VI. Terdapat empat mega proses dan dibagi sesuai dengan fungsinya masing-masing, serta informasi tersebut memerlukan integrasi dengan Sistem Informasi Institusi maupun Sistem Informasi Eksekutif yang dibutuhkan oleh IBI KKG dalam melakukan analisa terhadap kegiatan operasional.

\section{Perangkat Keras}

Pengembangan infrastruktur jaringan akan menggunakan backbone fibre optics ataupun jaringan kabel yang mampu mencapai hingga 1 Gigabyte 
TABEL 5 .

ROADMAP JARINGAN DAN INFRASTRUKTUR

\begin{tabular}{llll}
\multicolumn{3}{c}{ ROADMAP JARINGAN DAN INFRASTRUKTUR } \\
\hline Action Plan & $2010-$ & $2015-$ & $2020-$ \\
& 2015 & 2020 & 2025 \\
\hline Soho Netwo- & & & \\
rk Topology & & & \\
Mini Data & & & \\
Center & \\
Fiber Optic \\
\& Wifi Net- \\
work \\
Virtual Ser- \\
ver Techno- \\
logy \\
Enterprise \\
Network \\
Topology \\
Enterprise \\
Network \\
Topology - \\
Automation \\
Enterprise \\
Network \\
Topology - \\
Analytic \& \\
Integrated \\
High Availa- \\
bility Server- \\
Clustering \\
High Availa- \\
bility Server- \\
Fail Over \\
Full Mirorri- \\
ng Data Ce- \\
nter \\
\hline
\end{tabular}

dari setiap titik utama serta diharapkan hingga ke end-users. Topologi infrastruktur dan jaringan dapat dilihat pada Lampiran Gambar VII. Target pengembangan Jaringan dan infrastruktur hingga tahun Q4-2014 adalah membentuk Mini Data Center dalam ling-kungan kampus IBI KKG. Pengem-bangan selan-jutnya adalah membentuk ISP Kampus yang me-mpunyai band-width yang besar dan dapat diguna-kan untuk akses dari luar kampus untuk kebutuhan mahasiswa, dosen dan karyawan, kebutuhan untuk e-learning ataupun distance learning serta dapat pula untuk digunakan bagi pihak eksternal yang ingin menggunakan ISP IBI KKG.

Pengembangan perangkat keras komputer akan digunakan dengan beberapa server yang akan berfungsi yaitu sebagai: sirewall maupun VPN, $e$ mail server, SMS gateway, file server/data management (perpustakaan, data riset maupun lainnya), database server, peremajaan komputer lab serta peralatannya komputer lainnya.

Proses pengembangan dalam target 1 tahun ke depan hingga Q4-2014 adalah penyusunan jaringan dan infrastruktur yang reliable, optimize serta integrated. Kegiatan pengembangan yang akan dilakukan adalah perbaikan infrastruktur yang menunjang terhadap kegiatan pembelajaran, yaitu pe-
TABEL 6.

\begin{tabular}{lccc}
\multicolumn{4}{c}{ ROADMAP SISTEM INFORMASI AKADEMIK } \\
\hline \multirow{2}{*}{ Action Plan } & $2005-$ & $2010-$ & $2015-$ \\
& 2010 & 2015 & 2020 \\
\hline Student & & & \\
Administration & & & \\
Student & & \\
Accounting & & & \\
Teaching And & & & \\
Study & & & \\
Event & & & \\
Planning & & & \\
\hline
\end{tabular}

TABEL 7. ROADMAP SISTEM INFORMASI PENDUKUNG

\begin{tabular}{llll}
\hline \multirow{2}{*}{ Action Plan } & $2005-$ & $2010-$ & $2015-$ \\
& 2010 & 2015 & 2020 \\
\hline E-Library & & & \\
E-Journal & & & \\
E-Learning & & & \\
Web Site Ibi & & & \\
Kkg & & & \\
\hline
\end{tabular}

TABEL 8

\begin{tabular}{lccc}
\multicolumn{5}{c}{ TABEL 8 } \\
ROADMAP & SISTEM INFORMASI INSTITUSI \\
\hline \multirow{2}{*}{ Action Plan } & $2005-$ & $2010-$ & $2015-$ \\
& 2010 & 2015 & 2020 \\
\hline E-Security & & & \\
E-Procurement & & & \\
E-Inventory & & & \\
E-Asset & & \\
Finance \& & & \\
Accounting & & \\
Human Capital & & & \\
\& Management & & \\
\hline
\end{tabular}

mbangunan awal mini data center yang dapat digunakan untuk seluruh sivitas akademik, akses online terhadap sistem informasi akademik, peremajaan jaringan kabel serta penggunaan konsep client-server pada kelas laboratorium komputer maupun kelas pembelajaran dalam lingkungan kampus IBI KKG. Target Q2-2014, dukungan jaringan maupun infrastruktur untuk kebutuhan document management system sudah dapat digunakan oleh dosen dan karyawan. Tahap 2, memasuki tahun kedua pengembangan pada awal Q1-2016 hingga Q4-2018 adalah menyusun dan membangun jaringan infrastruktur terkait dukungan terhadap sistem informasi eksekutif, pengembangan menyeluruh terhadap penggunaan client-server untuk seluruh karyawan IBI KKG serta meningkatkan penggunaan akses informasi dijital secara terpadu yang digambarkan pada Lampiran Gambar VIII.

\section{Organisasi dan Sumber Daya Manusia IT}

Departemen IT diusulkan langsung di bawah rektor untuk menghindari penyalahgunaan tujuan dan wewenang organisasi. Struktur yang diusulkan untuk departemen IT pada Lampiran Gambar VIII. Struktur ini hanya memfokuskan departemen IT untuk menye-laraskan kebutuhan organisasi atau 
TABEL 9. ROADMAP SISTEM INFORMASI EKSEKUTIF

\begin{tabular}{lccc}
\hline \multirow{2}{*}{ Action Plan } & $2010-$ & $2015-$ & $2020-$ \\
& 2015 & 2020 & 2025 \\
\hline Dataware & & & \\
House & & & \\
Business & & & \\
Intellegence & & & \\
\hline
\end{tabular}

institusi dan bukan kebutuhan atau kepentingan departemen atau perorangan.

Berdasarkan hasil penelitian ini maka didapat roadmap pengembangan SI/TI di institusi ini, seperti tercantum pada Tabel 5-10.

\section{Kesimpulan}

Beberapa kesimpulan yang dapat diambil dari penelitian ini adalah sistem informasi dalam institusi akademik IBI KKG membutuhkan dukungan top manajemen yang konsisten mengingat adanya jabatan fungsional dosen di dalamnya. Selain itu, dibutuhkan pula biaya, waktu dan sumber daya yang tidak sedikit, high skilled, serta stabil.

Pengembangan infrastruktur dan jaringan dikembangkan sesuai dengan kebutuhan dan sistem informasi yang akan diimplementasikan pada institusi. Pengembangan sistem informasi akademik dan orangtua dapat dilakukan secara internal, tetapi untuk sistem pendukung dan ekesekutif sangat disarankan menggunakan Enterprise Resources Planning (ERP) yang terintegrasi sehingga dapat menghemat biaya dan waktu pengembangan sistem informasi.

Seiring dengan implementasi sistem dan teknologi informasi maka dibutuhkan unit training untuk pembelajaran secara berkala untuk para karyawan baru serta karyawan lama mengingat masih banyaknya generasi $\mathrm{x}$ dan y pada institusi tersebut. Peningkatan standar sumber daya manusia untuk para stakeholder dan pengguna sistem dan teknologi informasi di institusi ini harus dilakukan sesuai dengan SPMI.

Kestabilan dan kesolidan tim di departemen IT harus dipersiapkan, tidak hanya dari segi kemampuan dan keahlian mengingat dalam masa peralihan departemen IT akan menjadi problem solver center atau semua pengembangan SI/TI menjadi terhambat.

Perencanaan strategis di atas merupakan rekomendasi bagi pihak manajemen dan panduan implementasi dan pengembangan SI/TI di Institusi ini untuk departemen IT saat ini dan di masa depan.
TABEL 10.

\begin{tabular}{llll}
\multicolumn{4}{c}{ ROADMAP RESTRUKTURISASI ORGANISASI } \\
\hline \multirow{2}{*}{ Action Plan } & $2005-$ & $2010-$ & $2015-$ \\
& 2010 & 2015 & 2020 \\
\hline Restrukturisasi & & & \\
Organisasi & & & \\
Hard Skill & & & \\
Soft Skill & & & \\
\hline
\end{tabular}

\section{Referensi}

[1] Djanali, Supeno. "Menuju World Class University". 2007. [Online]. Available http:// www.scribd.com/doc/7174741/MenujuWorld-Class-University. [Diakses April 12, 2007].

[2] The Higher Education Supplement. "Weighting Scheme for Ranking Scores". 2010. [Online]. Available http://www.thes.co.uk/. [Diakses March 09, 2010].

[3] ARWU. "Academic Rangking of World Universities". 2005. [Online]. Available http:// www.arwu.org/. [Diakses March 09, 2005].

[4] Webometrics. "Ranking Web of Universities". 2005. [Online]. Available http://www. webometrics.info/en/Methodology. [Diakses April 25, 2016].

[5] Kaplan, Robert S. (2010). Conceptual Foundations of the Balanced Scorecard. Havard Business School.

[6] Kaplan, R. S., \& Norton, D. P. (1996). The balanced scorecard: translating strategy into action. Harvard Business Press.

[7] Zachman, J. (2002). The zachman framework for enterprise architecture. Zachman International, 79.

[8] Zachman, J. A. (1996). Concepts of the framework for enterprise architecture. Los Angels, CA.

[9] Lainhart IV, J. W. (2000). COBIT ${ }^{\mathrm{TM}}$ : A methodology for managing and controlling information and information technology risks and vulnerabilities. Journal of Information Systems, 14(s-1), 21-25.

[10] Simonsson, M., Johnson, P., \& Wijkström, H. (2007, June). Model-based IT governance maturity assessments with COBIT. In ECIS (pp. 1276-1287).

[11] Van Grembergen, W., De Haes, S., \& Amelinckx, I. (2003). Using COBIT and the balanced scorecard as instruments for service level management. Information Systems Control Journal, 4, 56-62. 


\section{Lampiran}

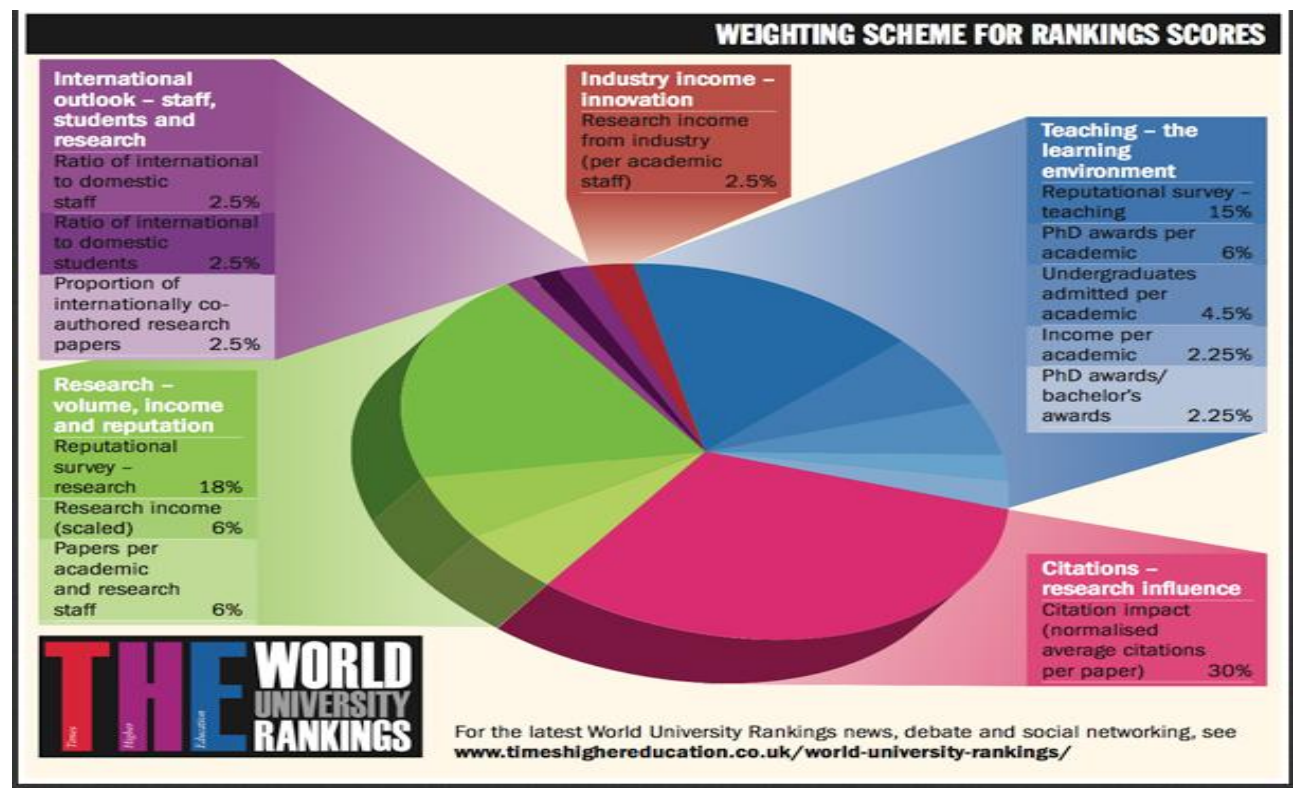

Lampiran Gambar I. Skema Penilaian THES

\begin{tabular}{|c|c|c|c|c|c|c|}
\hline & $\begin{array}{l}\text { DATA } \\
\text { What }\end{array}$ & $\begin{array}{c}\text { FUNCTION } \\
\text { How }\end{array}$ & $\begin{array}{l}\text { NETWORK } \\
\text { Whore }\end{array}$ & $\begin{array}{l}\text { PEOPLE } \\
\text { Who }\end{array}$ & $\begin{array}{l}\text { TIME } \\
\text { Whon }\end{array}$ & $\begin{array}{l}\text { MOTIVATION } \\
\text { Why }\end{array}$ \\
\hline $\begin{array}{l}\text { Objective/scope } \\
\text { (contextual) } \\
\text { Rolo: Planner }\end{array}$ & $\begin{array}{l}\text { List of things } \\
\text { important in } \\
\text { the business }\end{array}$ & $\begin{array}{l}\text { List of } \\
\text { Business } \\
\text { Processes }\end{array}$ & $\begin{array}{l}\text { List of } \\
\text { Business } \\
\text { Locations }\end{array}$ & $\begin{array}{l}\text { List of } \\
\text { important } \\
\text { Organizations }\end{array}$ & $\begin{array}{l}\text { List of } \\
\text { Events }\end{array}$ & $\begin{array}{l}\text { List of } \\
\text { Business Goal } \\
\& \text { Strategies }\end{array}$ \\
\hline $\begin{array}{l}\text { Enterprise Model } \\
\text { (concoptual) } \\
\text { Role: Owner }\end{array}$ & $\begin{array}{l}\text { Conceptual } \\
\text { Datai } \\
\text { Object Model }\end{array}$ & $\begin{array}{l}\text { Business } \\
\text { Process } \\
\text { Model }\end{array}$ & $\begin{array}{l}\text { Business } \\
\text { Logistics } \\
\text { System }\end{array}$ & $\begin{array}{l}\text { Work } \\
\text { Flow } \\
\text { Model }\end{array}$ & $\begin{array}{l}\text { Master } \\
\text { Schedule }\end{array}$ & $\begin{array}{l}\text { Business } \\
\text { Plan }\end{array}$ \\
\hline $\begin{array}{l}\text { System Model } \\
\text { (logical) } \\
\text { Role:Designer }\end{array}$ & $\begin{array}{l}\text { Logical } \\
\text { Data } \\
\text { Model }\end{array}$ & $\begin{array}{l}\text { System } \\
\text { Architecture } \\
\text { Model }\end{array}$ & $\begin{array}{l}\text { Distributed } \\
\text { Systems } \\
\text { Architecture }\end{array}$ & $\begin{array}{l}\text { Hurnan } \\
\text { interface } \\
\text { Architecture }\end{array}$ & $\begin{array}{l}\text { Processing } \\
\text { Structure }\end{array}$ & $\begin{array}{l}\text { Business } \\
\text { Rule } \\
\text { Model }\end{array}$ \\
\hline $\begin{array}{l}\text { Technology Model } \\
\text { (physical) } \\
\text { Role:Builder }\end{array}$ & $\begin{array}{l}\text { Physical } \\
\text { Data/Class } \\
\text { Model }\end{array}$ & $\begin{array}{l}\text { Technology } \\
\text { Design } \\
\text { Model }\end{array}$ & $\begin{array}{l}\text { Technology } \\
\text { Architecture }\end{array}$ & $\begin{array}{l}\text { Presentation } \\
\text { Architecture }\end{array}$ & $\begin{array}{l}\text { Control } \\
\text { Structure }\end{array}$ & $\begin{array}{l}\text { Rule } \\
\text { Design }\end{array}$ \\
\hline $\begin{array}{l}\text { Dotaled Reprentation } \\
\text { (out of contect) } \\
\text { Robe: Programmor }\end{array}$ & $\begin{array}{l}\text { Data } \\
\text { Definition }\end{array}$ & Program & $\begin{array}{l}\text { Network } \\
\text { Architecture }\end{array}$ & $\begin{array}{l}\text { Security } \\
\text { Architecture }\end{array}$ & $\begin{array}{l}\text { Timing } \\
\text { Definition }\end{array}$ & $\begin{array}{l}\text { Rulo } \\
\text { Speculation }\end{array}$ \\
\hline $\begin{array}{l}\text { Functioning } \\
\text { Enterprise } \\
\text { Role: User }\end{array}$ & $\begin{array}{l}\text { Usable } \\
\text { Data }\end{array}$ & $\begin{array}{l}\text { Working } \\
\text { Function }\end{array}$ & $\begin{array}{l}\text { Usable } \\
\text { Network }\end{array}$ & $\begin{array}{l}\text { Functioning } \\
\text { Organization }\end{array}$ & $\begin{array}{l}\text { Implemented } \\
\text { Schedule }\end{array}$ & $\begin{array}{l}\text { Working } \\
\text { Strategy }\end{array}$ \\
\hline
\end{tabular}

Lampiran Gambar II. Zachman Framework (1996) 
Yunus Fadhillah, et al., Analisa dan Perencanaan Strategis Sistem dan Teknologi Informasi 25

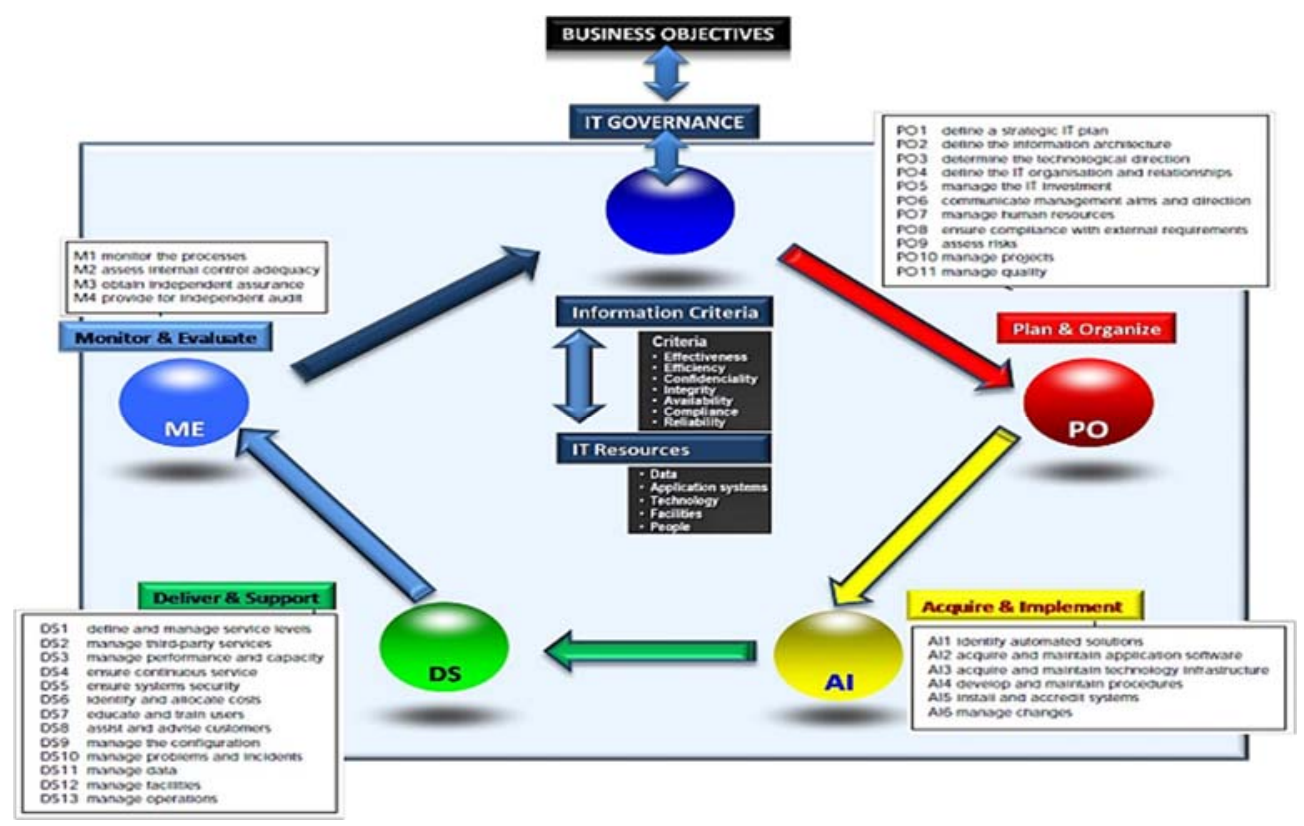

Lampiran Gambar III. COBIT Framework. (2000)

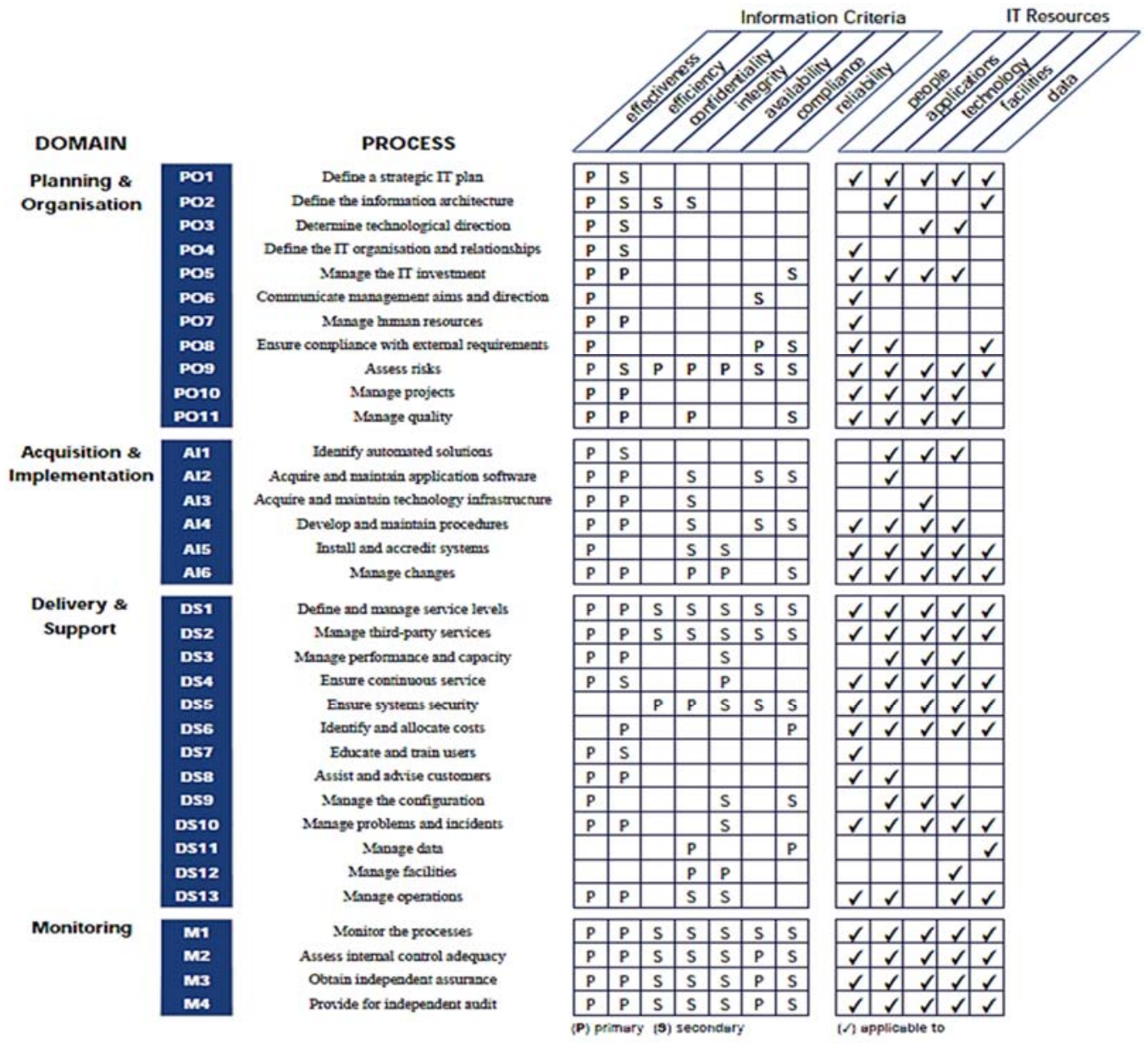

Lampiran Gambar IX. Activity Goals 


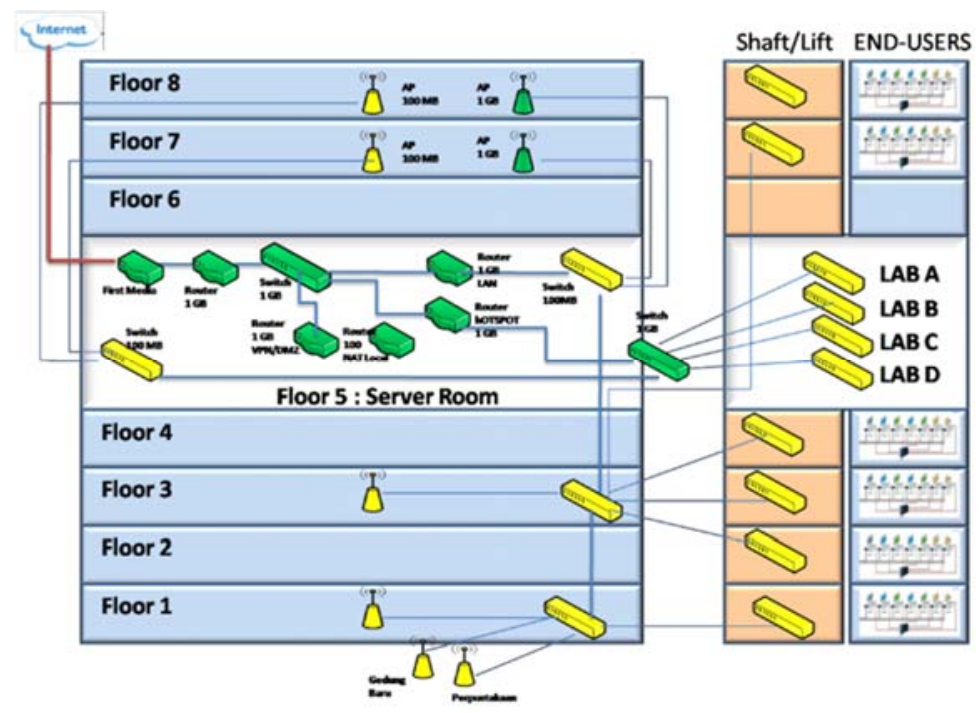

Lampiran Gambar V. Topologi Jaringan Saat Ini

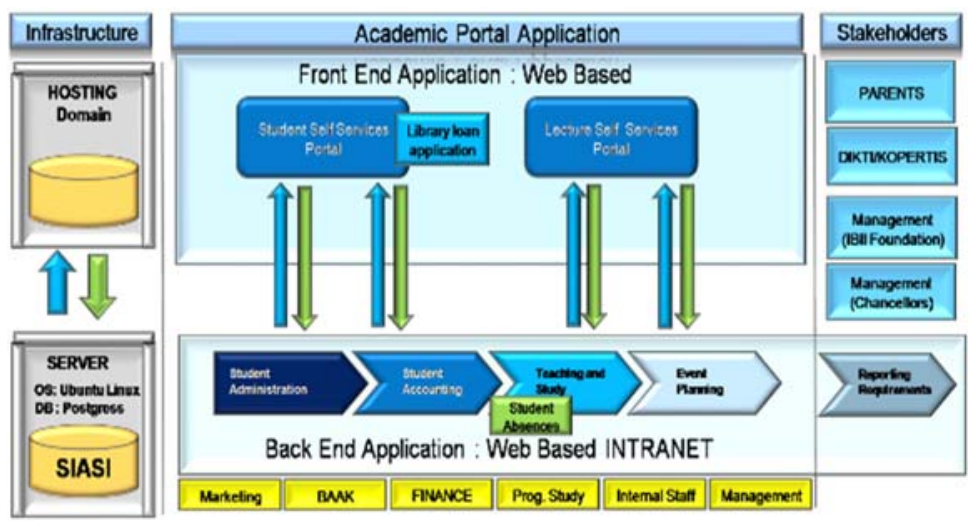

Lampiran Gambar VI. Rancangan Sistem Informasi Terintegrasi IBI KKG.

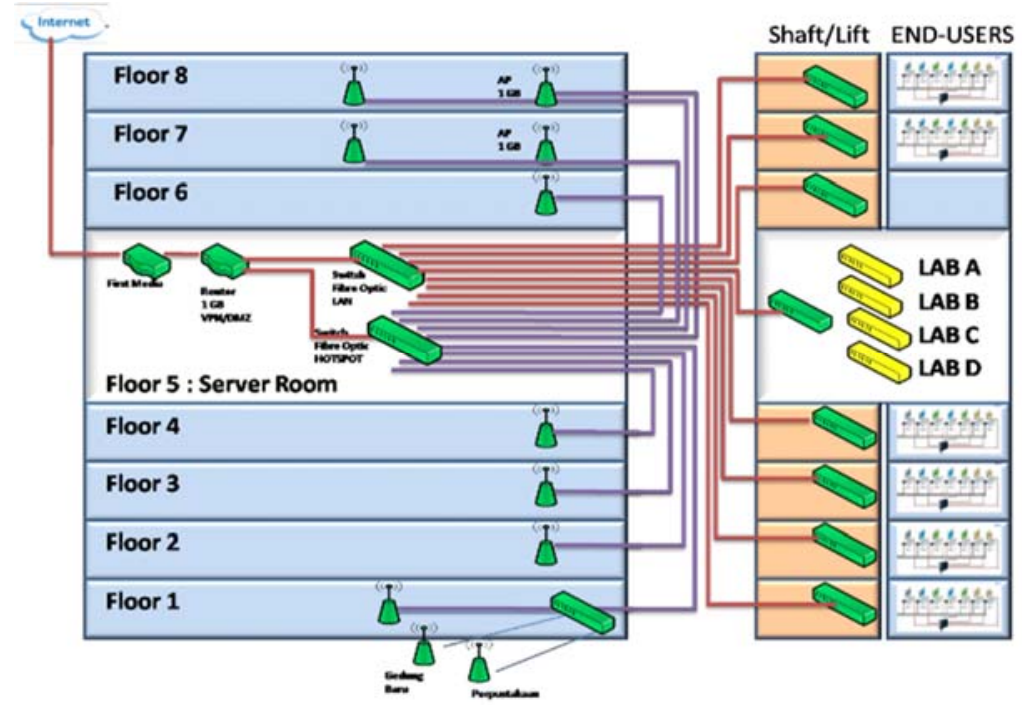

Lampiran Gambar VII. Topologi Jaringan IBI KKG 
Yunus Fadhillah, et al., Analisa dan Perencanaan Strategis Sistem dan Teknologi Informasi 27

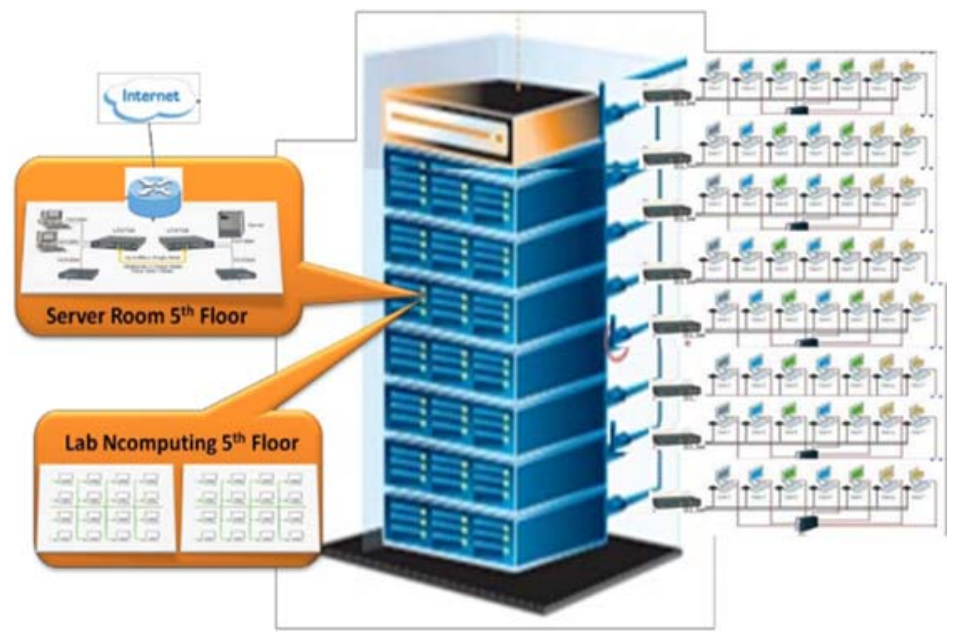

Lampiran Gambar VIII. Konsep Konfigurasi Jaringan Gedung

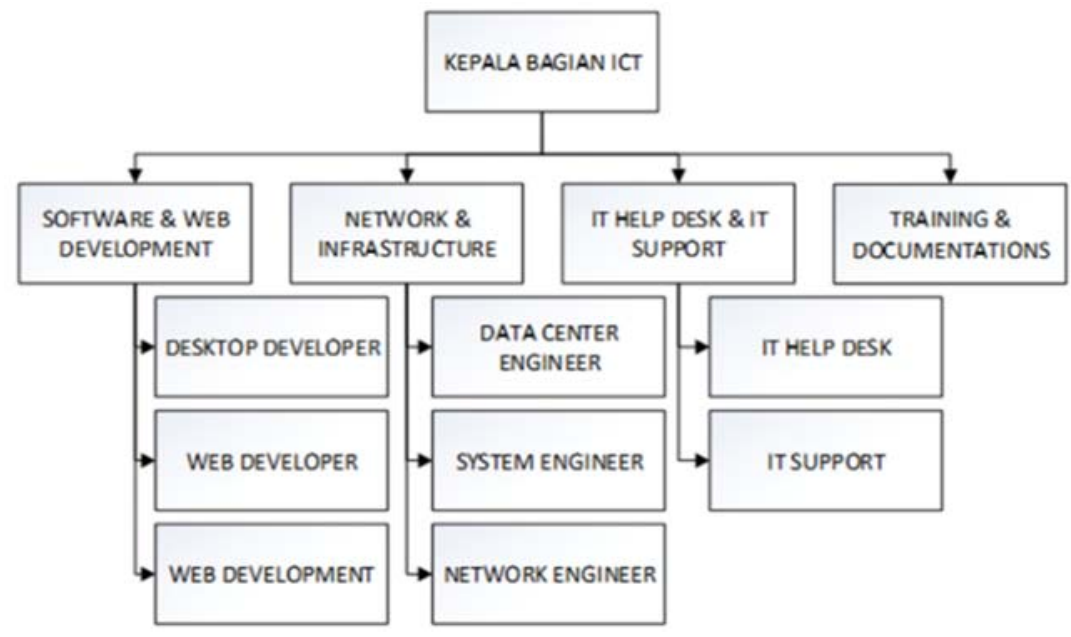

Lampiran Gambar XI. Usulan Struktur Organisasi IT di IBI KKG 
LAMPIRAN TABEL I

KRITERIA WORLD CLASS UNIVERSITY DITJEN DIKTI

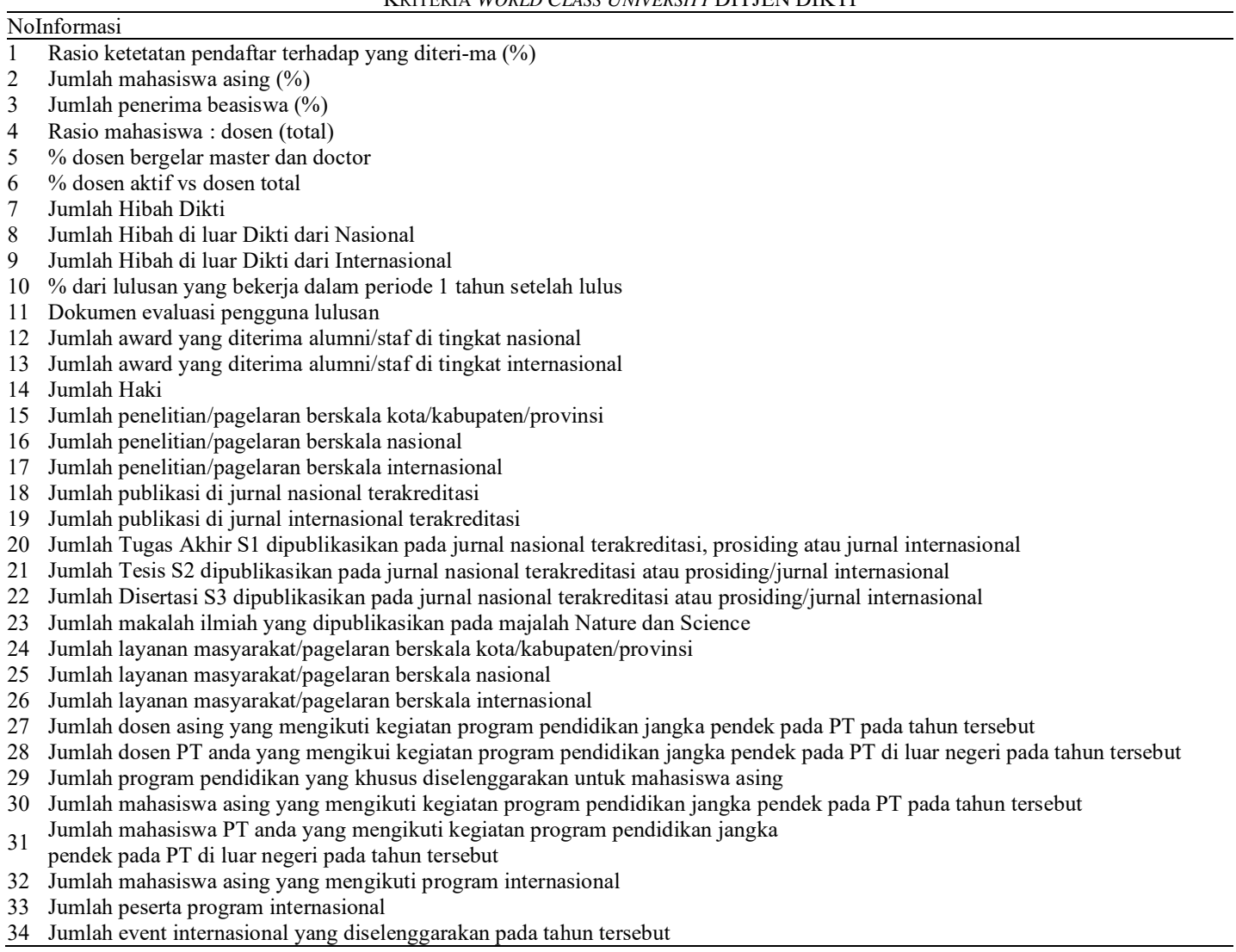

LAMPIRAN TABEL II.

HASIL ANALISIS KEBUTUHAN \& KESENJANGAN SiSTEM INFORMASI

\begin{tabular}{|c|c|c|c|}
\hline Unit Kerja & $\begin{array}{l}\text { Ringkasan kondisi Pelayanan } \\
\text { Informasi yang berjalan }\end{array}$ & Isu/Status & Kebutuhan Informasi \\
\hline Rektorat & Belum ada & $\begin{array}{l}\text { Belum dapat menganalisa terhadap } \\
\text { seluruh data dari seluruh bagian } \\
\text { yang ada }\end{array}$ & $\begin{array}{l}\text { Sistem Informasi Eksekutif atau biasa dikenal } \\
\text { dengan analysis reporting untuk Institut IBI KKG }\end{array}$ \\
\hline $\begin{array}{l}\text { Wakil } \\
\text { Rektor } 1\end{array}$ & Belum ada & $\begin{array}{l}\text { Belum dapat mengetahui dan } \\
\text { menganalisa terhadap seluruh data } \\
\text { AKADEMIK }\end{array}$ & $\begin{array}{l}\text { Sistem Informasi Eksekutif atau biasa dikenal } \\
\text { dengan analysis reporting untuk Institut IBI KKG }\end{array}$ \\
\hline $\begin{array}{l}\text { Divisi } \\
\text { BAAK }\end{array}$ & $\begin{array}{l}\text { Sistem Informasi (SI) } \\
\text { Kemahasiswaan yang saat ini } \\
\text { baru digunakan untuk S1 dan S2 } \\
\text { program MM, lebih dikenal } \\
\text { dengan SIASI }\end{array}$ & 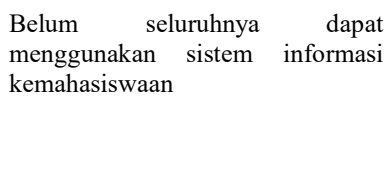 & $\begin{array}{l}\text { A. Integrasi penuh pada Marketing, Keuangan } \\
\text { maupun }\end{array}$ \\
\hline $\begin{array}{l}\text { Program } \\
\text { Studi }\end{array}$ & $\begin{array}{l}\text { SI Kemahasiswaan, pengisian } \\
\text { Nilai hasil Ujian, Jadwal Ujian } \\
\text { maupun Kuliah, Informasi } \\
\text { mengenai Dosen Pengajar }\end{array}$ & $\begin{array}{l}\text { Belum bisa memperoleh data } \\
\text { kegiatan AKADEMIK secara } \\
\text { langsung }\end{array}$ & Dapat melihat data secara langsung dan online \\
\hline $\begin{array}{l}\text { Divisi } \\
\text { Perpustakaan }\end{array}$ & $\begin{array}{l}\text { Pelayanan katalog online sudah } \\
\text { dimiliki }\end{array}$ & $\begin{array}{l}\text { Hanya merupakan proses } \\
\text { pencatatan buku perpustakaan serta } \\
\text { terdapat sistem kecil untuk } \\
\text { peminjaman buku perpustakaan }\end{array}$ & 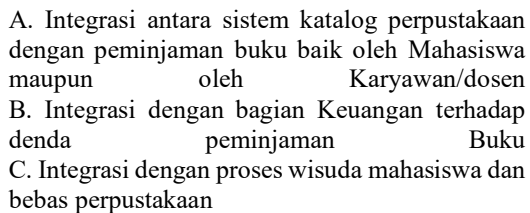 \\
\hline
\end{tabular}




\begin{tabular}{|c|c|c|c|}
\hline Unit Kerja & $\begin{array}{l}\text { Ringkasan kondisi Pelayanan } \\
\text { Informasi yang berjalan }\end{array}$ & Isu/Status & Kebutuhan Informasi \\
\hline $\begin{array}{l}\text { Divisi Unit } \\
\text { Pengendali } \\
\text { Ujian }\end{array}$ & $\begin{array}{l}\text { Informasi masih dijalankan } \\
\text { secara manual }\end{array}$ & $\begin{array}{l}\text { Hanya didasari dari jadwal } \\
\text { akademik dan disusun secara } \\
\text { manual untuk kebutuhan jadwal } \\
\text { Ujian }\end{array}$ & $\begin{array}{l}\text { Integrasi terhadap sistem Integrated Academic } \\
\text { Portal (IAP) }\end{array}$ \\
\hline $\begin{array}{l}\text { Wakil } \\
\text { Rektor II }\end{array}$ & $\begin{array}{l}\text { Belum dapat online secara } \\
\text { menyeluruh, baru memiliki } \\
\text { sistem presensi saja }\end{array}$ & $\begin{array}{l}\text { Kebutuhan informasi yang saling } \\
\text { terkait antar divisi ibawah sub- } \\
\text { ordinat WaRek II, masih } \\
\text { dilakukan secara manual }\end{array}$ & $\begin{array}{l}\text { A. Integrasi dari Sistem Human Capital } \\
\text { Management } \\
\text { B. Integrasi terhadap Sistem Pembelian, } \\
\text { Inventory, maupun logistik serta informasi } \\
\text { mengenai data kemahasiswaan }\end{array}$ \\
\hline $\begin{array}{l}\text { Divisi } \\
\text { Rumah } \\
\text { Tangga \& } \\
\text { Umum }\end{array}$ & $\begin{array}{l}\text { Mash dilakukan secara manual } \\
\text { khususnya untuk kebutuhan } \\
\text { asset dan Inventory }\end{array}$ & $\begin{array}{l}\text { Proses masih dilakukan dengan } \\
\text { pencatatan saja, akan tetapi } \\
\text { pemutakhiran data tidak berjalan } \\
\text { dengan baik }\end{array}$ & $\begin{array}{l}\text { Sistem informasi yang dapat memberikan } \\
\text { mengenai perpindahan asset dan pencatatan } \\
\text { inventory }\end{array}$ \\
\hline $\begin{array}{l}\text { Divisi } \\
\text { Pembelian }\end{array}$ & $\begin{array}{l}\text { Proses pelaksanaan pembelian } \\
\text { masih menggunakan } \\
\text { Spreadsheet }\end{array}$ & $\begin{array}{l}\text { Proses permintaan barang, harus } \\
\text { dilakukan secara manual dan } \\
\text { diolah kembali oleh bagian } \\
\text { Pembelian. Informasi berjalan } \\
\text { secara manual kepada bagian } \\
\text { Keuangan }\end{array}$ & $\begin{array}{l}\text { Sistem informasi yang dapat mendukung untuk } \\
\text { keperluan pembelian dan integrasi dengan } \\
\text { inventory yang ada. }\end{array}$ \\
\hline
\end{tabular}

Divisi Proses perhitungan presensi Proses pelaporan presensi masih Integrasi data dengan Bagian Kemahasiswaan Personalia masih dilakukan oleh Bagian diberikan secara manual kepada mengenai data dosen pengajar, serta informasi ICT bekerjasama dengan seluruh bagian. Informasi belum kepada karyawan mengenai data presensi Bagian Personalia. Selain itu, terkait dengan bagian lainnya maupun permintaan administrasi tentang pencatatan data karyawan terhadap cuti karyawan atau kepegawaian masih belum dapat dilihat oleh aktivitas lainnya

bagian lain yang berkepentingan untuk dapat memantau mengenai kegiatan presensi karyawan

Wakil Proses masih Informasi kemahasiwaan,

Rektor III dilakukan manual khususnya untuk IPK yang rendah belum dapat diperoleh secara tepat waktu, informasi yang terkait dengan subordinat masih berjalan secara manual

\begin{abstract}
A. informasi data mengenai prestasi Kemahasiswaan B. Informasi mengenai aktivitas konseling

C. Informasi mengenai data Alumni dan Tracer Study D. Integrasi dengan bagian lainnya yang terkait, sehubungan dengan informasi mengenai pembayaran kegiatan perkuliahan, jadwal maupun kegiatan kerjasama dengan Pihak Eksternal
\end{abstract}

\footnotetext{
LPPM Data belum ada Informasi masih dilakukan manual

Divisi Data masih tersebar dan Sebagai sentraslisasi sumber data Integrasi antar Divisi, baik dari bagian Keuangan sebagian besar masih yang mengacu pada kegiatan kemahasiswaan maupun bagian lainnya dalam dilakukan secara manual keuangan belum sepenuhnya lingkungan IBI KKG berjalan dengan sistem

Divisi Informasi mengenai calon Belum optimal dalam proses Integrasi yang menyeluruh mulai dari proses Marketing mahasiswa sudah dapat integrasi dengan bagian lainya, penerimaan mahasiswa hingga proses $\begin{array}{llrl}\text { dilakukan dengan sistem } & \begin{array}{l}\text { khususnya dengan bagian pencatatan keuangan mengenai proses } \\ \text { keuangan }\end{array} & \text { pembayaran mahasiswa baru. Selain itu, }\end{array}$ informasi mengenai Student Relation Management masih perlu untuk dikembangkan lebih detil.
} 